\title{
POŠTA
}

TELEKOMUNIKÁCIE A

ELEKTRONICKY OBCHOD

\section{KVALITA VZDELÁVANIA Z POHLADU MOŽNOSTI UPLATNENIA ABSOLVENTOV ŠTUDIJNÉHO PROGRAMU ELEKTRONICKÝ OBCHOD A MANAŽMENT V PODNIKATELSKOM PROSTREDÍ SLOVENSKEJ REPUBLIKY}

\author{
Emília Madudová*, Lukáš Vartiak
}

\section{Úvod}

Štúdium na vysokej škole, univerzite sa stalo v dnešnej dobe nevyhnutným kritériom pre úspešné uplatnenie na trhu práce. Pri celkovom vysokom počte univerzít a vysokých škôl na Slovensku, je čoraz jednoduchšie pre študentov stredných škôl získanie vysokoškolského titulu. Príspevok hodnotí kvalitu študijného programu Elektronický obchod a manažment na Žilinskej univerzite v Žiline, Fakulte prevádzky a ekonomiky dopravy a spojov, Katedre spojov z pohl'adu možností uplatnenia absolventov spomínaného programu na trhu práce. Hodnotí kvalitu získaných teoretických vedomostí a praktických zručností pre začatie podnikania absolventov spomínaného programu vpodmienkach Slovenskej republiky, vychádzajúc z predpokladu, že uplatnenie absolventa v praxi by malo byt' pri výbere vysokej školy jedným z rozhodujúcich kritérií. Prvá kapitola príspevku je venovaná teoretickým východiskám riešenej problematiky, druhá kapitola sa venuje analýze súčasného stavu nielen na Slovensku ale aj v zahraničí, hodnotí stav podnikatel'ského prostredia, i konkurenciu ponúkaných programov so zameraním na elektronický obchod a manažment. Metodiku prieskumu bližšie popisuje tretia kapitola, za ktorou nasleduje samotné priblíženie výsledkov práce a diskusia. Záver sumarizuje všetky zistené skutočnosti.

\section{Teoretické východiská}

Žilinská univerzita vo svojej činnosti nadväzuje na celosvetový vývoj vedy, techniky, umenia a kultúry a prispieva tak svojou činnost'ou k rozvoju vzdelanosti, čím pripravuje svojich študentov na uplatnenie nielen u zamestnávatel'ov, ale aj pre samostatnú podnikatel'skú činnost'. [11]

V roku 2006 vznikol pod záštitou Katedry spojov na Fakulte prevádzky a ekonomiky dopravy a spojov nový bakalársky študijný program elektronický obchod a manažment (EOaM), odbor Odvetvové ekonomiky a manažment. V roku 2009 odobrila akreditačná komisia na základe žiadosti aj druhý, inžiniersky stupeň štúdia programu elektronický obchod a manažment. Po troch rokoch a získaní titulu bakalár tak môžu študenti pokračovat' a snažit' sa o titul inžinier. [3]

Špecifickou čast'ou programu sú bloky predmetov orientované na využitie informačných a komunikačných technológií a služieb v podnikatel'ských procesoch, obchode a marketingu (Príloha B). Realizácia týchto predmetov sa okrem odborného zázemia Katedry

\footnotetext{
* Ing. Emília Madudová, PhD., Žilinská univerzita v Žiline, Univerzitná 8215/1, FPEDAS, Katedra spojov , tel.: +421415133116

e-mail: Emilia.Madudova@fpedas.uniza.sk
} 
spojov opiera tiež o vedecký a pedagogický potenciál pracovníkov Katedry telekomunikácií, Elektrotechnickej fakulty, Žilinskej univerzity v Žiline. [2]

Študijný program elektronický obchod a manažment ako pomerne nový študijný program na Žilinskej univerzite pripravuje svojich študentov na riešenie, analyzovanie a syntetické posudzovanie problémov a možností v podnikatel'ských aktivitách rôznych typov podnikov.

Absolvent tohto programu tak mal byt' schopný sa uplatnit' v každej zo šiestich známych právnych foriem podnikania na Slovensku, ako aj vo všetkých troch nadnárodných právnych foriem $\mathrm{v}$ rámci EÚ. Absolvent EOaM tiež vd'aka znalostiam z psychológie trhu, komunikácie so zákazníkmi, informačných systémov a technológií, projektového manažmentu a hodnotového manažmentu by mal byt' schopný analyzovat' indexy hodnotiace podnikatel'ské prostredie v SR aj v EÚ a dokáže sa tak rozhodnút', či je pre neho vhodné v danom okamihu podstúpit' podnikatel'ské riziko.

\section{Analýza súčasného stavu}

Podl'a údajov celoštátneho štatistického zist'ovania o cene práce ISCP vypočítaných spoločnost'ou Trexima Bratislava zarobia stredoškolsky vzdelaní l'udia počas celého produktívneho veku spravidla $380000 €$ a zamestnanci so skončenou vysokou školou takmer $530000 €$. Absolutórium z vysokej školy teda prinesie slovenskému zamestnancovi o 150000 $€$ vyšší celoživotný zárobok. A to napriek tomu, že vysokoškoláci začínajú reálne pracovat' zvyčajne o pät' rokov neskôr než stredoškoláci. [7]

Žiadna zo slovenských univerzít a vysokých škôl neponúka študijný program, ktorý by bol totožný s študijným programom EOaM. Tento študijný program je teda na Slovensku jedinečný. Existujú však študijné programy s podobnými profilmi absolventa: Manažment FRI ŽU ZA, Manažment - FM UK BA, Manažérske rozhodovanie a informačné technológie - FHI EU BA.

Na rozdiel od Slovenska, v ostatných vyspelých krajinách sveta existuje mnoho univerzít a vysokých škôl, ktoré ponúkajú študijné programy zaoberajúce sa elektronickým obchodovaním (E-Commerce / E-Business).

$\mathrm{V}$ rámci EÚ má so študijným programom EOaM najviac spoločného program Elektronické obchodovanie so štúdiom Manažmentu na Kingston University v Londýne. Tento program poskytuje poznatky a kvalifikáciu potrebnú pre návrh, vývoj a implementáciu aplikácií a technológií elektronického obchodovania. Úlohou programu je umožnit' technológiám elektronického obchodovania prezentovat' sa v širšom podnikatel'skom, sociálnom a ekonomickom kontexte. Program je navrhnutý tak, aby obohatil kariérne možnosti a nadviazal na predchádzajúce skúsenosti za účelom zlepšit pracovný výkon a umožnit' rozvoj tímovej práce a schopnosti viest' tím. [4]

Štúdium zamerané na elektronické obchodovanie je pravdepodobne najviac rozšírené v USA, čoho dôkazom je množstvo študijných programov zaoberajúcich sa elektronickým obchodovaním, ktoré ponúkajú americké univerzity a vysoké školy. Mnohé z univerzít ponúkajú elektronické obchodovanie ako samostatný študijný program, no sú aj také, ktoré dávajú možnost' zamerat' sa na elektronický obchod v rámci podnikového hospodárstva alebo manažmentu. Ked’že svetovým trendom je internetové vzdelávanie, niektoré z týchto programov sú vyučované formou internetových kurzov. [8]

Prehl'ad najznámejších študijných programov v USA, zameraných na elektronické obchodovanie zhŕňa tabul'ka 1.

Tabul'ka 1.Prehl'ad najznámejších programov E-Commerce/E-Business v USA

\begin{tabular}{|c|c|c|c|}
\hline $\begin{array}{c}\text { Názov univerzity/vysokej } \\
\text { školy }\end{array}$ & Rok založenia & $\begin{array}{c}\text { Názov študijného } \\
\text { programu }\end{array}$ & $\begin{array}{c}\text { Dosiahnuté vzdelanie } \\
\text { ukončené titulom. }\end{array}$ \\
\hline
\end{tabular}




\begin{tabular}{|l|l|l|l|}
\hline University of Phoenix & 1976 & Elektronické podnikanie & Bc. \\
\hline Walden University & 1970 & $\begin{array}{l}\text { Riadenie informačných } \\
\text { systémov }\end{array}$ & Mgr. \\
\hline Clarkson University & 1896 & $\begin{array}{l}\text { Elektronické } \\
\text { obchodovanie }\end{array}$ & Mgr. \\
\hline DePaul University & 1989 & $\begin{array}{l}\text { Elektronické } \\
\text { obchodovanie }\end{array}$ & Mgr. \\
\hline $\begin{array}{l}\text { Western Michigan } \\
\text { University }\end{array}$ & 1903 & $\begin{array}{l}\text { Dizajn elektronického } \\
\text { obchodovania }\end{array}$ & Mgr. \\
\hline
\end{tabular}

Zdroj: THE BEST COLLEGES. 2010-05-04. The 10 Best E-Commerce / E-Business Degree Programs. [online].

[cit. 2012-11-16]. URL: <http://www.thebestcolleges.org/the-10-best-e-commerce-e-business-degree-

programs/>.

Každoročne úspešne absolvuje vysokoškolské štúdium na Slovensku niekol'ko tisíc študentov. Domáci pracovný trh im však dlhodobo nedokáže poskytnút' dostatočný počet pracovných miest.

Podl'a údajov Ústredia práce, sociálnych vecí a rodiny bola nezamestnanost' na Slovensku v marci 2013 vo výške 431382 osôb, z toho 2233 absolventov VŠ. To predstavovalo nezamestnanost' na úrovni $14,68 \%$. Pričom najviac nezamestnaných bolo $\mathrm{v}$ Prešovskom kraji (88 959, z toho 443 absolventov VŠ) a najmenej nezamestnaných v Bratislavskom kraji (21 660, z toho 138 absolventov VŠ). Žilinský kraj bol s počtom nezamestnaných 47184 (z toho 261 absolventov VŠ) po Bratislavskom, Trnavskom a Trenčianskom kraji štvrtý v poradí. [9]

Údaje o uplatnení absolventov v praxi sústred’uje aj Ministerstvo školstva s pomocou ústredia práce. (Tabul'ka 2) Výsledky tejto štatistiky však môžu ovplyvnit' rôzne vedl'ajšie faktory, ktoré treba zohl'adnit' (počet študentov jednotlivých VŠ, vek absolventov, počet externých študentov VŠ, počet študentov so zahraničným občianstvom, miera nezamestnanosti v regióne). [6]

Tabul'ka 2. Prehl'ad miery nezamestnanosti absolventov podobných študijných programov programu EOaM.

\begin{tabular}{|l|l|l|}
\hline Univerzita & Fakulta & Nezamestnanost' \\
\hline Žilinská univerzita v Žiline & FPEDAS & $6,58 \%$ \\
\hline Žilinská univerzita v Žiline & FRI & $4,02 \%$ \\
\hline Univerzita Komenského v Bratislave & FM & $0,73 \%$ \\
\hline Ekonomická univerzita v Bratislave & FHI & $4,55 \%$ \\
\hline
\end{tabular}

Zdroj: PODNIKATELSKÁ ALIANCIA SLOVENSKA. 2012. Prepad kvality podnikatel'ského prostredia sa zrýchluje. 2012-03-14. [online]. [cit. 2013-03-27]. URL: < http://alianciapas.sk/category/pravidelne_aktivity/ index_podnikatelskeho_prostredia/>.

Prvé miesto v hodnotení miezd absolventov zastáva Slovenská technická univerzita a Ekonomická univerzita v Bratislave s priemernou hrubou mzdou $984 €$, d'alej absolventi Ekonomickej univerzity $\mathrm{v}$ Bratislave $\mathrm{s}$ priemernou hrubou mzdou $910 €$ a absolventi Univerzity Komenského v Bratislave s priemernou hrubou mzdou $841 €$. Najmenej zarábali študenti Univerzity J. Selyeho v Komárne. Absolventi Žilinskej univerzity v Žiline skončili na štvrtom mieste s priemernou hrubou mzdou $784 €$. [6]

Spoločnost' Trexima v spolupráci s Republikovou úniou zamestnávatel'ov, Asociáciou zamestnávatel'ských zväzov a združení SR a Konfederáciou odborových zväzov SR spoločne realizujú projekt „Národná sústava povolaní“. Projekt je financovaný z Európskeho sociálneho fondu v rámci Operačného programu Zamestnanost' a sociálna inklúzia a bol vytvorený, aby sa stal kl'účovým prvkom pri predvídaní potrieb trhu práce. Ciel’om projektu je zostavit' verejne dostupný národný register zamestnaní slovenského trhu práce, ktorý umožní rýchlu orientáciu v ponukách vzdelávania. [1]

Problémy pri predvídaní potrieb trhu práce vyplývajúce z výsledkov prieskumu projektu:

1. nefungujúci systém zberu informácií o požiadavkách zamestnávatel’ov, 
2. Národný register povolaní a Národný register kvalifikácií definujú existujúce povolania a kvalifikácie, ale nezohl'adňujú budúce potreby trhu práce,

3. neexistencia sektorových analýz súčasných a budúcich rozdielov medzi dopytom a ponukou na trhu práce,

4. štátne i neštátne inštitúcie vyvíjajú vlastné aktivity spojené so sledovaním trhu práce a jeho potrieb, ale jednotlivé projekty sú realizované bez vzájomného prepojenia,

5. nedostatok existujúcich partnerstiev vysokých škôl a podnikov. [28]

Správa Podnikatel'skej aliancie Slovenska (PAS), ktorá hodnotí podnikatel'ské prostredie na Slovensku na základe indexu IPP hovorí o pokračujúcom zhoršení podnikatel'ského prostredia na Slovensku. Hodnota IPP za štvrtý štvrt'rok 2012, je 75,60 bodu, čo je najnižšia hodnota vo viac ako 10 ročnej histórii meraní. V porovnaní s predchádzajúcim štvrt'rokom klesol index o 4,43\%.

Národná agentúra pre rozvoj malého a stredného podnikania zverejnila v júni 2012 správu s názvom „Správa o stave malého a stredného podnikania v Slovenskej republike v roku 2011 “. Správa vychádza z údajov Štatistického úradu SR, podl'a ktorých bolo v roku 2011 na Slovensku evidovaných 402325 fyzických osôb - podnikatel'ov. [5]

Hodnota IPP za štvrtý kvartál 2012 bola najnižšia hodnota vo viac ako 10 ročnej histórii meraní. Aj stav podnikatel'ského prostredia na Slovensku je teda nepriaznivý, a to aj v porovnaní s hodnotením podnikatel'ského prostredia v UK (kde na Kingston University v Londýne existuje študijný program Elektronické obchodovanie so štúdiom Manažmentu, ktorý má so študijným programom EOaM najviac spoločného), v ktorom $82 \%$ oslovených podnikatel'ov aj nad'alej považovalo Britániu za atraktívne miesto pre zriadenie alebo rozšírenie podnikania.

\section{Materiál a metodika}

Pre zhodnotenie skúmaného študijného programu bolo potrebné zostavit' prehl'adnú SWOT analýzu. Ciel'om tejto analýzy bolo zistit' oblasti, v ktorých má študijný program EOaM silné stránky a naopak, v ktorých má slabiny, príležitosti a hrozby, následne ohodnotit’ ich váhy, dôležitost' a efekt.

Spomínaný študijný program bol zhodnotený aj na základe názorov študentov a absolventov, ktoré boli získané prostredníctvom primárneho prieskumu formou dotazníka.

Vyhodnotenie prieskumu poskytlo obraz o pohl'ade študentov na štúdium v danom programe, ale aj o ich budúcom uplatnení po absolvovaní štúdia.

Prieskum bol anonymný a obsahoval štyri identifikačné otázky, šest' otázok týkajúcich sa štúdia v študijnom programe EOaM a devät' otázok zameraných na podnikanie a prínos štúdia v študijnom programe EOaM.

Dotazník bol odoslaný (celkovému počtu) 68 študentom druhého ročníka denného inžinierskeho štúdia $\mathrm{v}$ študijnom programe elektronický obchod a manažment, pričom ho vyplnilo 63 študentov, z toho 41 žien a 22 mužov vo veku 22 až 25 rokov.

Na základe hore uvedených skutočností, predstavuje spol'ahlivost' odhadu $95 \%$ a maximálne prípustné rozpätie chýb $H=3,5 \%$.

Najviac respondentov bolo zo žilinského kraja (67 \%), d'alej $13 \%$ z trenčianskeho kraja, $8 \%$ z banskobystrického a prešovského kraja a $2 \%$ z košického, trnavského a nitrianskeho kraja. Nadpolovičná väčšina respondentov (59\%) počas štúdia aj pracuje.

Vyhodnotenie prieskumu poskytlo tiež obraz o pohl'ade absolventov na štúdium $\mathrm{v}$ danom programe, ale aj o ich budúcom uplatnení po absolvovaní štúdia.

Prieskum bol tiet' anonymný a obsahoval sedem identifikačných otázok a rovnako ako u študentov šest' otázok týkajúcich sa štúdia v študijnom programe EOaM a devät' otázok zameraných na podnikanie a prínos štúdia v študijnom programe EOaM. 
Dotazník bol odoslaný 30 absolventom denného inžinierskeho štúdia v študijnom programe elektronický obchod a manažment, pričom ho vyplnilo 28 absolventov, $\mathrm{z}$ toho 16 žien a 12 mužov vo veku 23 až 27 rokov.

Na základe hore uvedených skutočností, predstavuje spol'ahlivost' odhadu $95 \%$ a maximálne prípustné rozpätie chýb $H=5 \%$.

Absolventi ukončili štúdium v rokoch 2011 (14 \%) a 2012 (86 \%). Najviac respondentov bolo zo žilinského kraja (54\%), d’alej $21 \% \mathrm{z}$ trenčianskeho kraja, $11 \% \mathrm{z}$ banskobystrického a 4 \% z košického, nitrianskeho, prešovského a trnavského kraja. predpoklady:

Na základe predchádzajúcich zistení, boli stanovené nasledovné výskumné

- VP1: Viac ako 50 \% opýtaných študentov študijného programu elektronický obchod a manažment si myslí, že získavajú počas štúdia dostatočné teoretické vedomosti pre potreby začatia podnikania.

- VP2: Viac ako 50 \% opýtaných študentov študijného programu elektronický obchod a manažment si myslí, že získavajú počas štúdia dostatočné praktické zručnosti pre potreby začatia podnikania.

- VP3: Viac ako 50 \% opýtaných absolventov študijného programu elektronický obchod a manažment si myslí, že získali počas štúdia dostatočné teoretické vedomosti pre potreby začatia podnikania.

- VP4: Viac ako 50 \% opýtaných absolventov študijného programu elektronický obchod a manažment si myslí, že získali počas štúdia dostatočné praktické zručnosti pre potreby začatia podnikania

\section{Výsledky a diskusia}

Výstupom SWOT analýzy študijného programu elektronický obchod a manažment matica z ktorej vyplynulo, že študijný program EOaM, by sa mal riadit' ofenzívnou stratégiou, pretože silné stránky prevládajú nad slabými a príležitosti prevládajú nad hrozbami. Teda vzhl'adom na silu študijného programu EOaM (jedinečnost' študijného programu, kvalifikovanost' a skúsenost' pedagogického kolektívu) je možné využit' ponúknuté príležitosti (stúpajúci záujem kvalifikovaných pedagógov pôsobit' $\mathrm{v}$ študijnom programe, stúpajúci záujem o štúdium v študijnom programe).

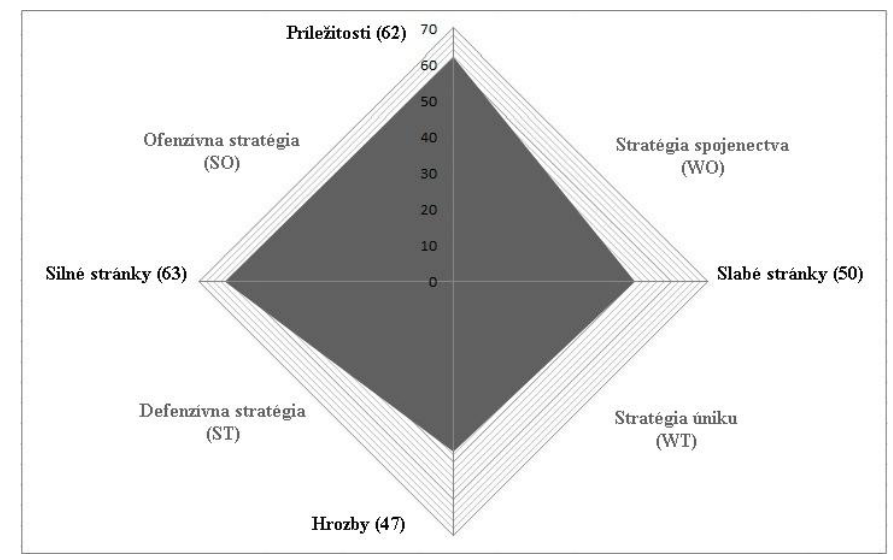

Obrázok 28. Graf SWOT analýzy študijného programu EOaM Zdroj: Vlastné spracovanie podla [10]

Netreba však zabúdat' na slabé stránky (vysoké pedagogické zat'aženie učitel'ov, nedostatočná úspešnost' v získavaní garantov medzinárodného významu) a hrozby s vysokou závažnost'ou a pravdepodobnost'ou výskytu, ktoré môžu študijný program EOaM negatívne 
ovplyvnit' (rastúci počet vysokých škôl, vznik podobného študijného programu a s tým spojený odchod kvalifikovaných pedagógov z programu EOaM).

Z realizovaného prieskumu, medzi študentmi druhého ročníka denného inžinierskeho štúdia v študijnom programe elektronický obchod a manažment bolo zrejmé, že až $41 \% \mathrm{z}$ opýtaných sa o študijnom programe EOaM dozvedelo od kamarátov a známych, ktorí študovali alebo študujú v tomto programe, 62 \% respondentov si študijný program EoAM vybralo kvôli zameraniu na elektronické obchodovanie, $43 \%$ opýtaných očakávalo získanie dostatočných vedomostí a zručností pre manažérsku funkciu, 77 \% opýtaných študentov by uvítalo zavedenie povinnej praxe do štúdia, $62 \% \mathrm{z}$ nich uvažovalo nad zamestnaním na Slovensku, 70 \% dotazovaných študentov nemalo záujem o doktorandské štúdium, 38 \% respondentov vyjadrilo, že nad samostatným podnikaním neuvažuje.

Ďalej sa $54 \%$ opýtaných študentov vyjadrilo, že získavajú počas štúdia dostatočné teoretické vedomosti potrebné pre začatie podnikania, $49 \%$ respondentov sa vyjadrilo, že nezískavajú počas štúdia dostatočné praktické zručnosti potrebné pre začatie podnikania, 84 \% opýtaných študentov sa vyjadrilo, že štúdium im poskytuje aktuálne informácie o legislatívnych a právnych predpisoch z oblasti podnikania, pre $34,19 \%$ respondentov mal najväčší teoretický prínos pre potreby začatia podnikania predmet „Obchodno-finančné vzt’ahy“, pre 40,43 \% respondentov mal najväčší praktický prínos pre potreby začatia podnikania opät' predmet „Obchodno-finančné vzt’ahy“, $63,93 \%$ opýtaných študentov sa vyjadrilo, že v rámci štúdia im z oblasti podnikania najviac chýba prax a praktické skúsenosti, 57 \% respondentov nevedelo aj o iných možnostiach vzdelávania $v$ oblasti podnikania pre študentov Žilinskej univerzity mimo základných predmetov v rámci štúdia v odbore EOaM, 55 \% opýtaných študentov sa vyjadrilo, že štúdium $\mathbf{v}$ danom študijnom programe ich postoj $\mathbf{k}$ podnikaniu neovplyvnilo.

Z prieskumu, ktorý bol realizovaný medzi absolventmi denného inžinierskeho štúdia v študijnom programe elektronický obchod a manažment vyplynulo, že 68 \% respondentov si študijný program EoAM vybralo kvôli zameraniu na elektronické obchodovanie, 43 \% opýtaných očakávalo lepšie uplatnenie na trhu práce vd'aka absolventskému titulu, $71 \%$ respondentov sa vyjadrilo, že ich očakávania sa naplnili len čiastočne, 57 \% opýtaných absolventov hodnotí štúdium v študijnom programe EOaM pozitívne, 61 \% dotazovaných absolventov uplatňuje získané poznatky z vysokej školy aj v praxi len čiastočne, 41,94 \% respondentov navrhuje zavedenie povinnej praxe do štúdia, 57 \% opýtaných absolventov sa vyjadrilo, že získali počas štúdia dostatočné teoretické vedomosti potrebné pre začatie podnikania, $50 \%$ respondentov sa vyjadrilo, že nezískali počas štúdia dostatočné praktické vedomosti potrebné pre začatie podnikania, $57 \%$ opýtaných absolventov sa vyjadrilo, že štúdium im poskytovalo aktuálne informácie o legislatívnych a právnych predpisoch z oblasti podnikania, 15,38 \% opýtaných absolventov sa vyjadrilo, že najväčší teoretický prínos pre potreby začatia podnikania pre nich mali predmety „Elektronický obchod“ a „Obchodno-finančné vzt'ahy“, 23,33 \% dotazovaných absolventov sa vyjadrilo, že pre nich mal najväčší praktický prínos pre potreby začatia podnikania opät' predmet „Elektronický obchod“, 33,33 \% respondentom v rámci štúdia z oblasti podnikania najviac chýbala prax a praktické skúsenosti, 82 \% opýtaných absolventov nevyužilo aj iné možnosti vzdelávania $v$ oblasti podnikania pre študentov Žilinskej univerzity mimo základných predmetov v rámci štúdia v odbore EOaM, 46 \% opýtaných absolventov malo neutrálny postoj $\mathbf{k}$ podnikaniu mali počas štúdia, 82 \% dotazovaných absolventov sa vyjadrilo, že štúdium $\mathbf{v}$ danom študijnom programe ich postoj $k$ podnikaniu neovplyvnilo.

Na základe získaných odpovedí z prieskumu medzi študentmi a absolventmi je možné overit' stanovené výskumné predpoklady nasledovne: 
- VP1: Prvý výskumný predpoklad bol stanovený na základe otázky v dotazníku pre študentov so znením: „Získavate počas štúdia dostatočné teoretické vedomosti potrebné pre začatie podnikania?“. Ked’že $54 \%$ opýtaných študentov odpovedalo kladne, len $16 \%$ záporne a $30 \%$ sa nevedelo vyjadrit', stanovený výskumný predpoklad je možné potvrdit'.

- VP2: Druhý výskumný predpoklad vychádzal z otázky v dotazníku pre študentov, ktorá znela: „Získavate počas štúdia dostatočné praktické zručnosti potrebné pre začatie podnikania? (napr.: vypracovanie podnikatel'ského plánu, počítanie odvodov, výpočet ceny úveru...)“. Tu sa $49 \%$ opýtaných študentov vyjadrilo záporne, $46 \%$ kladne a $5 \%$ sa nevedelo rozhodnút'. Tento výskumný predpoklad bol teda vyvrátený.

- VP3:Tretí výskumný predpoklad bol stanovený na základe otázky v dotazníku pre absolventov so znením: „Získali ste počas štúdia dostatočné teoretické vedomosti potrebné pre začatie podnikania?" Ked’že až 57 \% opýtaných absolventov odpovedalo kladne, len $18 \%$ záporne a $25 \%$ sa nevedelo vyjadrit', tretí výskumný predpoklad je možné potvrdit'.

- VP4: Štvrtý výskumný predpoklad vychádzal z ôsmej otázky v dotazníku pre absolventov, ktorá znela: „Získali ste počas štúdia dostatočné praktické zručnosti potrebné pre začatie podnikania? (napr.: vypracovanie podnikatel'ského plánu, počítanie odvodov, výpočet ceny úveru....“. Tu sa $50 \%$ opýtaných absolventov vyjadrilo záporne, len $36 \%$ kladne a $14 \%$ sa nevedelo rozhodnút'. Štvrtý výskumný predpoklad bol teda vyvrátený.

$\mathrm{Na}$ základe výsledkov analýzy teoretických východísk by mal byt' absolvent študijného programu EOaM schopný uplatnit' sa v každej zo šiestich známych právnych foriem podnikania $\mathrm{v}$ SR, ako aj vo všetkých troch nadnárodných právnych formách podnikania $\mathrm{v}$ rámci EÚ. Absolvent EOaM by tiež vd’aka získaným znalostiam mal byt' schopný analyzovat' indexy podnikatel'ského prostredia v SR aj v EÚ a rozhodnút' sa, či je pre neho v danom okamihu vhodné podstúpit' riziko podnikania.

Analýza súčasného stavu poskytla záver, že študijný program EOaM sa dá v podmienkach slovenského vysokého školstva považovat' za jedinečný, pričom na Slovensku existujú len podobné študijné programy ako EOaM, zhodujúce sa najmä v predmetoch, nie však v celkovom zameraní. Situácia v uplatnení absolventov VŠ na Slovensku (a teda aj absolventov EOaM) však nie je priaznivá. Nepriaznivý je aj stav podnikatel'ského prostredia na Slovensku a hodnota IPP neustále klesá.

\section{Záver}

Podla údajov celoštátneho štatistického zist'ovania o cene práce sú mzdy zamestnancov so skončenou vysokou školou takmer o tri štvrtiny vyššie ako u stredoškolsky vzdelaných l'udí. Absolutórium z vysokej školy teda podl'a zistení neprináša len vedomosti, ale aj vyššie finančné ohodnotenie.

V dnešnej modernej dobe význam informačno-komunikačných technológií každým dňom rastie a stávajú sa nevyhnutnou súčast'ou života l'udí. Rastie tak aj význam elektronického obchodovania. Študijný program EOaM sa dá v podmienkach slovenského vysokého školstva považovat' za jedinečný, pričom v zahraničí (najmä UK a USA) je mnoho univerzít a vysokých škôl, ktoré ponúkajú študijné programy zaoberajúce sa elektronickým obchodovaním.

Od roku 2009 stúpa priemerná nezamestnanost' na Slovensku a situácia v uplatnení absolventov VŠ nie je priaznivá. Nepriaznivý je aj stav podnikatel'ského prostredia na Slovensku a hodnota IPP je čoraz nižšia. 
Jediná možnost' na oživenie slovenského podnikatel'ského prostredia je dat' šancu mladým l'ud'om s novými nápadmi - absolventom.

Z realizovaného prieskumu, vyplynulo, že štúdium v danom študijnom programe síce poskytuje dostatočné teoretické vedomosti potrebné pre začatie podnikania, ako aj aktuálne informácie o legislatívnych a právnych predpisoch z oblasti podnikania, ale neposkytuje dostatočné praktické zručnosti potrebné pre začatie podnikania. Ked’že u podnikatel'ov čerstvých absolventov je vysoké riziko neúspechu práve kvôli nedostatočným skúsenostiam z oblasti podnikania, určite by im pomohlo získanie praktických zručností už počas štúdia.

\section{Literatúra}

[1] GOLIAŠ, P.: Sledovanie potrieb trhu práce. Bratislava, 2011, 26 s. [online]. [cit. 2012-1116]. URL: <www.ineko.sk/file_download/648>.

[2] KATEDRA SPOJOV, FAKULTY PREVÁDZKY A EKONOMIKY DOPRAVY A SPOJOV, ŽILINSKEJ UNIVERZITY V ŽILINE. 2004. Profil absolventa študijného odboru elektronický obchod a manažment. [online]. [cit. 2012-09-26]. URL: $<$ http://ks.utc.sk/profilEOaM>.

[3] KAVECKÝ L. 2009-07-19. E-obchod akreditovali. [online]. [cit. 2012-09-26]. URL: <http://zilina.sme.sk/c/4938537/e-obchod-akreditovali.html>.

[4] KINGSTON UNIVERSITY LONDON. 2013. Electronic Commerce with Management Studies Masters (MSc). [online]. [cit. 2012-11-16]. URL: $<$ http://www.kingston.ac.uk/postgraduate-course/electronic-commerce-managementmsc/\#modulelist>.

[5] NÁRODNÁ AGENTÚRA PRE ROZVOJ MALÉHO A STREDNÉHO PODNIKANIA: Správa o stave malého a stredného podnikania v Slovenskej republike $v$ roku 2011. Bratislava, 2012, 181 s. [online]. [cit. 2012-11-16]. URL: $<$ www.nadsme.sk/files/Stav_MSP_2011.pdf $>$.

[6] PODNIKATELSKÁ ALIANCIA SLOVENSKA. 2012. Prepad kvality podnikatel'ského prostredia sa zrýchluje. 2012-03-14. [online]. [cit. 2013-03-27]. URL: < http://alianciapas.sk/category/pravidelne_aktivity/index_podnikatelskeho_prostredia/>.

[7] TASR. 2012-03-01. Absolutórium z vysokej školy prinesie slovenskému zamestnancovi o 150.000 eur vyšší celoživotný zárobok. [online]. [cit. 2012-11-16]. URL: $<$ http://openiazoch.zoznam.sk/cl/118288/Absolvent-vysokej-skoly-zarobi-podstatne-viac>.

[8] THE BEST COLLEGES. 2010-05-04. The 10 Best E-Commerce / E-Business Degree Programs. [online]. [cit. 2012-11-16]. URL: <http://www.thebestcolleges.org/the-10-best-ecommerce-e-business-degree-programs/>.

[9] ÚSTREDIE PRÁCE, SOCIÁLNYCH VECÍ A RODINY. 2013. Nezamestnanost'-mesačné štatistiky. [online]. [cit. 2013-04-22]. $<$ http://www.upsvar.sk/statistiky/nezamestnanost-mesacne-statistiky.html?page_id=1254>.

[10] VARTIAK, L: Možnosti podnikania absolventov študijného programu elektronický obchod a manažment. Diplomová práca Žilina, 2013

[11] ŽILINSKÁ UNIVERZITA V ŽILINE: Výročná správa o činnosti Žilinskej univerzity v Žiline za rok 2011. Žilina, 2012, 23 s. [online]. [cit. 2012-09-26]. URL: <http://www.uniza.sk/document/sprava_ZU_2011/zakl_informacie.pdf>.

\section{Grantová podpora}

Príspevok vznikol za podpory nasledovných grantových projektov:

VEGA 1/0421/12 Modelovanie difúzie znalostí v podnikových hodnotových ret’azcoch Kvalita vzdelávania a rozvoj l'udských zdrojov ako piliere vedomostnej spoločnosti na Fakulte PEDAS Žilinskej univerzity v Žiline 26110230083 